\title{
Course Requirements for Bachelor's Degrees in Economics
}

\author{
By WiLliam Bosshardt, Michael Watts, AND William E. BecKER*
}

* Bosshardt: Florida Atlantic University (e-mail: wbosshar@fau.edu); Watts, Purdue University (e-mail: mwatts@purdue.edu); Becker, Indiana University (email: beckerw@indiana.edu). We thank xxx and xxx for comments.

The economics major has attracted a good deal of attention in journal articles, including sessions at annual meetings of the American Economic Association that were published as panel discussions in the AER Papers and Proceedings or the Journal of Economic Education. Most of these sessions featured general discourses by prominent economists on the goals and effectiveness of the major, with little or no new empirical evidence provided to support conclusions or conjectures and few references to the many empirical studies that have been done on teaching and learning in various undergraduate courses. ${ }^{1}$

Some more formal studies on the major have appeared, including papers on the use of writing and research assignments, especially in senior seminars and honors programs (McGoldrick 2008 and Siegfried 2001); how economics departments are responding to the recent wave of performance outcome requirements for undergraduate majors in all fields (Myers, Nelson, and Straton 2011); and a comparison of required and elective courses at top-ranked European and U.S. economics departments (Monteiro and Lopes 2007).

The earlier study that most directly relates to the new survey data we present here is a 1992 paper by Siegfried and Bidani (SB), which featured survey data on course requirements and electives for the undergraduate economics major collected in 1980 (Siegfried and Wilkinson

\footnotetext{
${ }^{1}$ For example, in 1982 a panel discussion at the AEA meetings on "The Economics Major: What It Is and What It Should Be" featured D. Gale Johnson, Robert J. Lampman, Bernard Saffron, and Robert Solow. In 1991, a paper at the AEA meetings on "The Economics Major: Can and Should We Do Better than a B-?" (Siegfried et al.) assigned the B- grade based on a survey of economists at 127 U.S. colleges and universities. In 2009, David Colander and KimMarie McGoldrick presented a white paper on the economics major as part of a liberal education at the annual AEA meetings. Their paper and several responses were published in the 2009 AER Papers and Proceedings, and then with a larger set of papers in their edited volume, Educating Economists: The Teagle Discussion on Re-evaluating the Economics Major (2009).
} 
1982), and looked at differences in requirements for departments housed in business schools. Dean and Dolan (2001) made some comparisons to the SB findings for a sample of 148 schools, but their sample was restricted to "primarily undergraduate institutions," intentionally excluding schools offering graduate degrees in economics.

Here we provide updated survey data on economics courses required for the BA and BS degrees in economics at institutions classified as research, doctoral, master's, and baccalaureate schools. This information was collected as a relatively small part of a longer survey addressing the question of how departments evaluate faculty teaching (Becker, Bosshardt, and Watts 2012).

\section{Survey Methods and Response Rates}

In February 2011 we mailed 774 questionnaires to chairs of economics departments using a mailing list provided by the American Economic Association. We restricted our sample to U.S. institutions offering a baccalaureate degree or higher, as classified by the Carnegie Foundation. As reported in more detail in Becker, Bosshardt, and Watts (2012), 182 surveys were returned for a response rate of 23.5 percent, ranging from 30.6 to 21.6 percent across the Carnegie classifications, after combining doctoral and research schools because we received only 11 responses from departments in doctoral schools.

Only $14 \%$ of our responses from Bachelors schools were from departments housed in a business college/unit, compared to $61 \%$ of responses from Masters schools and 32\% from Research and Doctoral schools. For the overall sample $38 \%$ of departments were in business schools. Across all Carnegie classifications a majority of respondents reported that their schools

offered undergraduate business degrees, with the percentage rising from $62 \%$ at Bachelors schools to $83 \%$ for Research and Doctoral schools and $100 \%$ at Masters schools. 


\section{Current Course Requirements for the BA and BS Degrees in Economics}

Ninety-eight departments reported offering only the BA, 15 offered only the BS, 62 offered both, and 7 offered neither (five of those at Master's schools). Twenty departments (29\%) housed in business schools/units offered only the BA; 10 (14\%) offered only the BS; and 33 $(48 \%)$ offered both. In departments located in non-business units, 78 (69\%) offered only the BA, only $5(4 \%)$ offered only the BS, and 29 (26\%) offered both.

Turning to course requirements for the BA and BS degrees, shown in the second and third columns of Table 1, about $85 \%$ or more of departments require a self-standing micro principles course, with about the same percentage requiring a macro principles course. In $83 \%$ of BA programs and $88 \%$ of BS programs both principles courses are required. Most other departments require the hybrid one-semester course. A few U.S. schools (e.g., MIT) do not require a principles course.

\section{[Insert Table 1 Here]}

Virtually all departments require intermediate theory courses in micro and macro for both the BA and BS. Over $90 \%$ require at least one semester of statistics, with about twice as many (31 vs. 15\%) of the BS programs requiring two semesters. An econometrics course is required in $56 \%$ of the BS programs and $41 \%$ of BA programs.

Money and banking courses are required in $25 \%$ of BS programs and $14 \%$ of BA programs. As noted above, the BS degree is somewhat more likely to be offered through Business schools/colleges, where money and banking courses were once widely required.

History of thought courses are required by about $15 \%$ of both BA and BS programs. As discussed below, this number has been surprisingly stable since 1980, while the economic 
history course has fallen off much more, to less than $2 \%$ for both degrees. U.S. economic history courses were also once required by many business schools, but that requirement has been widely dropped.

Behavioral/experimental course are rarely required, despite the growing popularity of the field/methodology in graduate programs and research articles. In part that probably reflects high costs (as a share of departmental non-salary budgets) associated with running controlled experiments in laboratory settings where "subjects" are paid to participate.

Senior seminars are required in a third of the BA programs and almost that often (29\%) in BS programs. Senior thesis requirements come in at about half that level (15\%) in both BA and BS programs. That probably reflects higher costs for a thesis requirement, including constraints entailed in fitting those requirements into typical semester or quarter systems.

\section{Comparison of BA and BS programs in Business and non-Business Academic "Homes"}

Some differences in course requirements for the undergraduate degrees in economics are related to whether a department is housed in a business or non-business unit. To show that, in Table 1 we report course requirements for BA and BS degrees broken down by those locations.

Looking first at BA course requirements, the one-semester hybrid principles course is more often required by departments not in business schools ( 24 vs. 13\%), which probably reflects the prevalence of business school requirements for a two-semester principles sequence for all business students. Two semesters of statistics are also more likely to be required by departments in business schools ( 28 vs. $8 \%$ ). We were surprised to find that econometrics is more likely to be required for the BA degree in departments not housed in business schools (50 vs. 25\%), but in part that may reflect the difference in the statistics BA vs. BS requirements noted above. The 
money and banking course is required more often (25 vs. 9\%) by departments in business schools, as discussed above; and so too is international economics (26 vs. $8 \%$ ).

For the BS degree differences across departments in business versus non-business academic units, we find mostly the same story as for the BA. One-semester principles courses are more often required by departments not in business schools ( 24 vs. 9\%), and the share of departments not in business schools that require the hybrid course is the same $(24 \%)$ for both the BA and BS. Two semesters of statistics are again more likely required by departments in business schools (37 vs. 24\%), but the difference is not as large as it is for the BA degree. Econometrics courses are again required by more departments not in business schools (68 vs. 48\%), and more likely required for the BS degree than the BA whether the department is in a business school or not. ${ }^{2}$ Mathematical economics courses are required for the BS by over a fourth of the departments not in business schools. We suspect that requirement is more common at schools that send large numbers of students to graduate programs in economics, which has historically included many strong liberal arts schools, although that number has been dropping. Courses in international and labor economics are somewhat more likely to be required at departments in business schools, probably reflecting an emphasis on international business and offering labor economics as a service elective for business students majoring in organizational behavior and human resource management.

\section{Comparisons to Siegfried and Bidani (1992)}

Our sample has $38 \%$ of departments in business schools versus SB's $31 \%$. SB do not report BA vs. BS comparisons, but instead use administrative locations of departments (business vs.

\footnotetext{
2 Johnson, Perry, and Petkus (2012) report that approximately $40 \%$ of economics major programs require at least one econometrics course based on data from 1,428 institutions.
} 
liberal arts), which we also provide. Carnegie classifications have changed since 1980, with the Bachelors classification replacing Comprehensive and LA I \& II.

For departments housed in business schools: $30 \%$ of the departments in our sample were at Research and Doctoral universities, compared to SB's 19\%; 10\% were at Bachelor's schools, compared to $11 \%$ of the SB sample at Liberal Arts I \& II; and $59 \%$ of our sample were at Master's schools, compared to $69 \%$ of the SB sample at Comprehensive institutions. For departments not in business schools: in our sample 39\% were at Research and Doctoral universities, 23\% at Masters schools; and 38\% at Bachelors schools. For the SB sample, 20\% of departments were housed at Research and Doctoral universities, 32\% at Comprehensive schools, and $48 \%$ at Liberal Arts I and II schools.

Comparing economics course requirements from 1980 reported in SB to our 2011 sample, the only major change is for the econometrics course, up from about 5\% in 1980 to about 50\% now. There are also some minor changes, with requirements for intermediate theory courses up slightly from around $90 \%$ to nearly $100 \%$, and as discussed earlier the money and banking course is now less often required, especially in business schools, where just over half (53\%) required the course in 1980. International economics is required at a small minority of schools, but more than in 1980 - up from less than $5 \%$ to over $15 \%$. History of thought requirements were surprisingly stable, ranging from 13-20\% at different types of schools in 1980 and from 14$17 \%$ in our sample. Statistics requirements are almost universal now, with $94 \%$ of BA degrees and $97 \%$ of BS degrees requiring at least one course and often two. SB did not report one vs. two semester requirements, but noted that statistics was required at $81 \%$ to $89 \%$ of departments. 


\section{Conclusion}

Over the past three decades the single biggest change in coursework required for the BA and BS degrees in economics has clearly been the rise in requiring econometrics. Other changes have been marginal. The econometrics requirement is in line with the recommendations from the 1991 report and assessment of the undergraduate major. The net effects of the other changes in course requirements for meeting the recommendations are debatable, but probably not large in any case.

The more important issue is almost certainly whether the way theory and field courses are being taught has changed since 1991, to address those recommendations. And related to that question, as noted by Goldin (1991), is whether or not textbooks for undergraduate courses have changed. Our sense is that courses and textbooks today are far more similar to what they were in 1991 than they are different, and there is evidence that teaching methods and the time economics faculty members are devoting to teaching have changed very little since the mid-1990s (Watts and Schaur 2011 and Harter, Becker, and Watts 2011). There is also evidence that student grades have risen in recent decades while student study time has sharply declined and leisure time has increased, encouraged or at least complicitly ratified through the mechanism of grade inflation (Babcock and Marks 2011). Not all of that is academic economists' fault, of course; but taken together it all raises a very serious question: Does the undergraduate economics major today still earn the grade of B- assigned by Siegfried et al. in 1991 - on either 1991 or current grading scales? 


\section{REFERENCES}

Babcock, Philip and Mindy Marks. 2011. "The Falling Time Cost of College: Evidence from Half a Century of Time-Use Data." Review of Economics and Statistics 93(2): 468-78.

Becker, William E., William Bosshardt, and Michael Watts. 2012. "How Departments of Economics Evaluate Teaching." Journal of Economic Education, 43(3): 325-33

Colander, David, and KimMarie McGoldrick, eds. 2009. Educating Economists: The Teagle Discussion on Re-evaluating the Economics Major. Cheltenham, U.K. and Northampton, Mass.: Elgar.

Dean, David H., and Robert C. Dolan. 2001. "Liberal Arts or Business: Does the Location of the Economics Department Alter the Major?" Journal of Economic Education, 32(1): 18-35.

Goldin, Claudia. 1991. The B- Economics Major: Can and Should We Do Better? Journal of Economic Education 22(3): 225-26.

Harter, Cynthia, William E. Becker, and Michael Watts. 2011. "Time Allocations and Reward Structures for US Academic Economists from 1995-2005: Evidence from Three National Surveys." International Review of Economics Education, 10(2): 6-27.

Johnson, Bruce K., John J. Perry, and Marie Petkus. 2012. "The Status of Econometrics in the Economics Major: A Survey.” Journal of Economic Education, 43(3): 315-24.

McGoldrick, KimMarie. 2008. "Writing Requirements and Economic Research Opportunities in the Undergraduate Curriculum: Results from a Survey of Departmental Practices." Journal of Economic Education, 39(3): 287-96.

Monteiro, Henrique, and Alexandra Ferreira Lopes. 2007. "A Benchmarking of the Undergraduate Economics Major in Europe and in the United States." International Review of Economics Education, 6(2): 9-26. 
Myers, Steven C., Michael A. Nelson, and Richard W. Stratton. 2011. "Assessment of the Undergraduate Economics Major: A National Survey." Journal of Economic Education, 42 (2): 195-99.

Siegfried, John J. 2001. "Principles for a Successful Undergraduate Economic Honors Program." Journal of Economic Education, 32(2): 169-77.

Siegfried, John J., Robin L. Bartlett, W. Lee Hansen, Allen C. Kelley, Donald N. McCloskey, and Thomas H. Tietenberg. 1991. "The Economics Major: Can and Should We Do Better than a B-?" American Economic Review: Papers and Proceedings, 81(2): 20-25.

Siegfried, John J., and Benu Bidani. 1992. "Differences between Economics Programs Located in Liberal Arts Colleges and in Business Schools." Journal of Economic Education, 23(2): $181-88$.

Siegfried, John J., and J. T. Wilkinson. 1982. "The Economics Curriculum in the United States: 1980." American Economic Review: Papers and Proceedings, 72(2): 125-38.

Watts, Michael, and Georg Schaur. 2011. "Teaching and Assessment Methods in Undergraduate Economics: A Fourth National Quinquennial Survey," Journal of Economic Education, 42(3): 294-309. 
Table 1 - Course Requirements for Bachelor's Degrees in Economics

\begin{tabular}{|c|c|c|c|c|c|c|c|c|}
\hline \multirow{2}{*}{$\begin{array}{l}\text { Numbers are } \\
\text { percentages, } \\
\text { except where noted } \\
\\
\text { Course }\end{array}$} & \multicolumn{2}{|c|}{ All Departments } & \multicolumn{2}{|c|}{ Not in Business } & \multicolumn{2}{|c|}{ Business } & \multicolumn{2}{|c|}{$\begin{array}{c}1980 \text { Course } \\
\text { Requirements } \\
\text { (Siegfried and Bidan } \\
\text { 1992) }\end{array}$} \\
\hline & $\begin{array}{c}\text { BA } \\
\text { degree }\end{array}$ & $\begin{array}{c}\text { BS } \\
\text { degree }\end{array}$ & $\begin{array}{c}\text { BA } \\
\text { degree }\end{array}$ & $\begin{array}{c}\text { BS } \\
\text { degree }\end{array}$ & $\begin{array}{c}\text { BA } \\
\text { degree }\end{array}$ & $\begin{array}{c}\text { BS } \\
\text { degree }\end{array}$ & $\begin{array}{l}\text { Liberal } \\
\text { Arts }\end{array}$ & Business \\
\hline $\begin{array}{l}\text { Principles Survey } \\
\text { Course }\end{array}$ & 21 & 16 & 24 & 24 & 13 & 9 & \multirow[t]{3}{*}{90} & \multirow{3}{*}{94} \\
\hline Micro Principles & 85 & 90 & 80 & 79 & 94 & 98 & & \\
\hline Macro Principles & 84 & 91 & 79 & 82 & 94 & 98 & & \\
\hline Intermediate Micro & 100 & 99 & 100 & 97 & 100 & 100 & 91 & 95 \\
\hline Intermediate Macro & 98 & 99 & 97 & 99 & 98 & 100 & 89 & 91 \\
\hline $\begin{array}{l}\text { Statistics, one } \\
\text { semester }\end{array}$ & 79 & 66 & 85 & 74 & 66 & 60 & \multirow[t]{2}{*}{81} & \multirow{2}{*}{89} \\
\hline $\begin{array}{l}\text { Statistics, two } \\
\text { semesters }\end{array}$ & 15 & 31 & 8 & 24 & 28 & 37 & & \\
\hline Econometrics & 41 & 56 & 50 & 68 & 25 & 48 & 5 & 5 \\
\hline $\begin{array}{l}\text { Mathematical } \\
\text { Economics }\end{array}$ & 6 & 19 & 7 & 26 & 4 & 13 & NA & NA \\
\hline Game Theory & 1 & 4 & 0 & 3 & 2 & 5 & NA & NA \\
\hline $\begin{array}{l}\text { Behavioral } \\
\text { Economics }\end{array}$ & 1 & 1 & 0 & 0 & 4 & 2 & NA & NA \\
\hline Money and Banking & 14 & 25 & 9 & 22 & 25 & 28 & 29 & 53 \\
\hline $\begin{array}{l}\text { International } \\
\text { Economics }\end{array}$ & 14 & 21 & 8 & 15 & 26 & 26 & 3 & 7 \\
\hline Labor Economics & 4 & 8 & 3 & 3 & 6 & 12 & NA & NA \\
\hline History of Thought & 15 & 16 & 14 & 15 & 17 & 16 & 13 & 20 \\
\hline Economic History & 2 & 1 & 1 & 0 & 4 & 2 & NA & NA \\
\hline Senior Seminar & 33 & 29 & 35 & 29 & 30 & 28 & NA & NA \\
\hline Senior Thesis & 15 & 16 & 17 & 15 & 11 & 16 & NA & NA \\
\hline $\begin{array}{l}\text { Average Number of } \\
\text { Required Courses } \\
\text { from list above }\end{array}$ & 6.3 & 7.0 & 6.2 & 6.8 & 6.6 & 7.1 & NA & NA \\
\hline Observations & 160 & 77 & 107 & 34 & 53 & 43 & 349 & 152 \\
\hline
\end{tabular}

Source: Authors' data and calculations, Siegfried and Bidani (1992). 